\title{
Evaluation of Eucalyptus citriodora essential oil on goat gastrointestinal nematodes
}

\author{
Avaliação do óleo essencial de Eucalyptus citriodora sobre nematóides gastrintestinais de caprinos \\ Iara Tersia Freitas Macedo ${ }^{1}$; Claudia Maria Leal Bevilaqua ${ }^{1 *}$; Lorena Mayana Beserra de Oliveira ${ }^{1}$; \\ Ana Lourdes Fernandes Camurça-Vasconcelos ${ }^{1}$; Luiz da Silva Vieira²; Sthenia dos Santos Albano Amóra ${ }^{3}$ \\ ${ }^{1}$ Laboratório de Doenças Parasitárias, Programa de Pós-Graduação em Ciências Veterinárias, Universidade Estadual do Ceará - UECE \\ ${ }^{2} \mathrm{EMBRAPA} / \mathrm{CNPC}$ \\ ${ }^{3}$ Universidade Federal Rural do Semi-Árido - UFERSA \\ Received January 17, 2011 \\ Accepted April 8, 2011
}

\begin{abstract}
Phytotherapy may be an alternative strategy for controlling gastrointestinal parasites. This study evaluated the anthelmintic efficacy of Eucalyptus citriodora essential oil (EcEO). The in vitro effects of EcEO were determined through testing the inhibition of egg hatching and larval development of Haemonchus contortus. EcEO was subjected to acute toxicity testing on mice, orally and intraperitoneally. The in vivo effects of EcEO were determined by the fecal egg count reduction test (FECRT) in goats infected with gastrointestinal nematodes. The results showed that $5.3 \mathrm{mg} \cdot \mathrm{mL}^{-1} \mathrm{EcEO}$ inhibited egg hatching by $98.8 \%$ and $10.6 \mathrm{mg} \cdot \mathrm{mL}^{-1}$ EcEO inhibited $H$. contortus larval development by $99.71 \%$. The lethal doses for $50 \%$ of the mice were 4153 and $622.8 \mathrm{mg} \cdot \mathrm{kg}^{-1}$, for acute toxicity orally and intraperitoneally. In the FECRT, the efficacy of EcEO and ivermectin was 66.25 and $79.16 \%$ respectively, on goat gastrointestinal nematodes eight days after treatment. EcEO showed in vitro and in vivo anthelmintic activity.
\end{abstract}

Keywords: Phytotherapy, anthelmintic, Haemonchus contortus, Trichostrongylus spp., toxicity.

\section{Resumo}

Fitoterapia pode ser uma estratégia alternativa para o controle de parasitas gastrintestinais. Este estudo avaliou a eficácia anti-helmintica do óleo essencial de Eucalyptus citriodora (OeEc). Os efeitos in vitro do OeEc foram determinados através do teste de eclosáo de ovos e inibiçáo do desenvolvimento larvar de Haemonchus contortus. O OeEc foi submetido ao teste de toxicidade aguda oral e intraperitoneal, em camundongos. Os efeitos in vivo do OeEc foram avaliados através do teste de redução da contagem de ovos nas fezes (FECRT) com caprinos infectados com nematóides gastrintestinais. Os resultados mostraram que $5,3 \mathrm{mg} \cdot \mathrm{mL}^{-1}$ OeEc inibiram $98,8 \%$ a eclosão de ovos e 10,6 mg.mL $\mathrm{mL}^{-1}$ OeEc inibiram $99,71 \%$ o desenvolvimento larvar de $H$. contortus. As doses letais para $50 \%$ dos camundongos foram de 4153 e $622,8 \mathrm{mg} \cdot \mathrm{kg}^{-1}$ pela via oral e intraperitoneal. No FECRT, a eficácia de OeEc e ivermectina foi de 66,25 e 79,16\%, respectivamente, em caprinos 8 dias após o tratamento. OeEc mostrou atividade anti-helmintica in vitro e in vivo.

Palavras-chave: Fitoterapia, anti-helmíntico, Haemonchus contortus, Trichostrongylus spp., toxicidade.

\section{Introduction}

Gastrointestinal nematode infections are a major factor reducing the economic productivity of livestock throughout the world (VIEIRA, 2008). These parasites are responsible for severe weight loss, diarrhea, anemia and early mortality, and all of these cause production losses, especially in small ruminants (DIEHL et al., 2004). Synthetic anthelmintics have been used

\footnotetext{
*Corresponding author: Claudia Maria Leal Bevilaqua

Programa de Pós-graduação em Ciências Veterinárias - PPGCV,

Faculdade de Veterinária - FAVET, Universidade Estadual do Ceará - UECE,

Av. Paranjana, 1700, Campus do Itaperi,

CEP 60740-000, Fortaleza - CE, Brazil;

e-mail: claudiamlb@yahoo.com.br
}

to minimize the losses caused by helminth infections. However, intensive use has led to the global emergence of multiple resistance to anthelmintic drugs in small ruminant nematodes (JACKSON; MILLER, 2006). Therefore, the search for new nematicidal substances remains a priority (GEARY et al., 1999). Substances produced from plants may represent an alternative for controlling gastrointestinal nematodes, since they have the advantage of sustainable supply and are ecologically acceptable (COSTA et al., 2008). The use of medicinal plants has been reported in treating various ailments, thereby increasing the interest in ethnomedical and ethnoveterinary cures (BIZIMENYERA et al., 2006). 
Eucalyptus citriodora (Myrtaceae) is a plant native to Australia, and is widely cultivated around the world. It is the most common species used in Brazil for extraction of essential oil (HASEGAWA et al., 2008). It is used in anti-inflammatory and antipyretic remedies for the symptoms of respiratory infections, such as colds, flu and sinus congestion (SILVA et al., 2003). The essential oil from the leaves is purported to have multiple medicinal applications, including use as antifungal and antibacterial agents (CIMANGA et al., 2002; RAMEZANI et al., 2002). There have also been reports demonstrating its activity against the tick Boophilus microplus (CHAGAS et al., 2002), against Coleoptera such as Acanthoscelides obtectus (MAZZONETTO; VENDRAMIM, 2003), Zabrotes subfasciatus and Callosobruchus maculatus (BRITO et al., 2006), and against the phytonematode Meloidogyne incognita (PANDEY et al., 2000).

The aim of the present study was to evaluate the potential anthelmintic effect of $E$. citriodora essential oil on goat gastrointestinal nematodes.

\section{Materials and Methods}

\section{Obtaining the essential oil}

Eucalyptus citriodora essential oil (EcEO) was purchased from Dierberger Óleos Essenciais Ltda (Barra Bonita, State of São Paulo, Brazil). To increase the aqueous solubility, the oil was diluted in 3\% polysorbate 80 (Tween 80 ) (Dinâmica ${ }^{\oplus}$ ).

\section{Egg hatch test}

The egg hatching test was performed based on the methodology described by Coles et al. (1992). Sheep experimentally infected with 5000 infective larvae of Haemonchus contortus were used as a source of fresh eggs of this parasite. $H$. contortus eggs were recovered as described by Hubert and Kerboeuf (1992). Briefly, $10 \mathrm{~g}$ of feces collected directly from the rectum, were mixed with distilled water and filtered through 590, 149, 101 and $30 \mu \mathrm{m}$ mesh sieves. $250 \mu \mathrm{L}$ of egg suspension, containing approximately 100 fresh eggs, and $250 \mu \mathrm{L}$ of EcEO at concentrations of $0.33,0.66,1.32,2.65$ and $5.3 \mathrm{mg} \cdot \mathrm{mL}^{-1}$ were incubated in test tubes for 48 hours at $25^{\circ} \mathrm{C}$. After this time, drops of Lugol were added to the tubes. The eggs and first larval stage (L1) were counted under a microscope. This test had two controls: a negative containing the diluent (3\% Tween 80$)$ and a positive control with $0.025 \mathrm{mg} \cdot \mathrm{mL}^{-1}$ of thiabendazole. Three repetitions with five replicates for each $E$. citriodora essential oil concentration and for each control were performed.

\section{Larval development test}

The larval development test (LDT) was performed using an aliquot of egg suspension obtained as described by Hubert and Kerboeuf (1992). The suspension was incubated for 24 hours at $37^{\circ} \mathrm{C}$ to obtain the $\mathrm{L} 1$. Following this, $1 \mathrm{~mL}$ of larval suspension containing approximately $250 \mathrm{~L} 1$, and $1 \mathrm{~mL}$ of EcEO at concentrations of $0.66,1.32,2.65,5.3$ and $10.6 \mathrm{mg} \cdot \mathrm{mL}^{-1}$, were incubated with $2 \mathrm{~g}$ of feces from a nematode-free sheep for 6 days at $25^{\circ} \mathrm{C}$. The third-stage larvae (L3) were then recovered as described by Roberts and O'Sullivan (1950) and were counted under a microscope. This test had two controls: a negative with 3\% Tween 80 and a positive with $0.008 \mathrm{mg} \cdot \mathrm{mL}^{-1}$ ivermectin. Three repetitions with five replicates for each oil concentration and for each control were conducted.

\section{Acute toxicity test in mice}

The care and handling of the animals used in the acute toxicity test were in accordance with the internationally accepted standard guidelines for use of animals, and the protocol was approved by the Ethics Committee of Ceará State University (number: 08332518-2).

For the acute toxicity tests, Swiss albino mice $(n=96)$ of both sexes, with average weight of $27.5 \mathrm{~g}$, were kept in polypropylene boxes and fed with commercial feed and water ad libitum. The mice were randomly divided into 12 groups $(\mathrm{n}=8)$ : $\mathrm{G} 1$ to $\mathrm{G} 5$ received 2000, 3000, 4000, 5000 and $6000 \mathrm{mg} \cdot \mathrm{kg}^{-1}$ of EcEO via oral administration; G6 received 3\% Tween 80 via the same route; G7 to G11 received 300, 400, 500, 600, and $700 \mathrm{mg} \cdot \mathrm{kg}^{-1}$ of EcEO via intraperitoneal administration; and G12 received 3\% Tween 80 via intraperitoneal administration. The animals were observed for general behavioral changes, signs of toxicity and mortality for 6 hours after treatment. After 24 hours, the total number of dead animals was ascertained and the lethal doses were calculated (LD10 and LD50).

\section{Chemical analysis}

The chemical composition of the EcEO used in this study was determined by means of gas chromatography (GC) and mass spectrometry (MS). The oil was analyzed in a Hewlett-Packard 5971 instrument using the following experimental conditions: DB- 1 coated fused silica capillary column $(30 \mathrm{~m} \times 0.25 \mathrm{~mm})$; carrier gas: helium; injector temperature: $250{ }^{\circ} \mathrm{C}$; detector temperature: $200{ }^{\circ} \mathrm{C}$; column temperature program: 35 to $180{ }^{\circ} \mathrm{C}$ at $48{ }^{\circ} \mathrm{C} / \mathrm{min}$ and then 180 to $250{ }^{\circ} \mathrm{C}$ at $10^{\circ} \mathrm{C} / \mathrm{min}$. For MS, the electron impact was $70 \mathrm{eV}$.

Compounds were identified according to their GC retention time, expressed through Kovat's index, which was calculated by means of the Van den Dool and Kratz equation using a hydrocarbon homologous series and by comparing the test compound mass spectra with those present in the National Institute for Standard Technology computer database (NIST; 62,235 compounds) and published spectra (ADAMS, 2001).

\section{Fecal egg count reduction test (FECRT)}

To evaluate the efficacy of EcEO on the gastrointestinal nematodes of goats, the fecal egg count reduction test (FECRT) was performed. Thirty goats of both sexes, aged from 12 to 16 months and weighing $30 \mathrm{~kg}$ on average, from the Embrapa research farm in the municipality of Sobral, were used. Individual fecal samples were collected to determine the level of gastrointestinal nematode infection using a modified McMaster technique 
(UENO; GONÇALVES, 1998). The goats were divided into three homogeneous groups $(\mathrm{n}=10)$, in which the mean egg count per gram (epg) in each group was 6000 . The groups were administered the following treatments orally: G1 (untreated animals) received water; G2 received $0.2 \mathrm{mg} . \mathrm{kg}^{-1}$ of ivermectin (Ivomec ${ }^{\oplus}$ : Merial) in accordance with the manufacturer's instructions; and G3 received $500 \mathrm{mg} \cdot \mathrm{kg}^{-1}$ of EcEO for three consecutive days. Fecal samples from each animal were collected on treatment day 0 and on days 8, 15 and 22 post-treatment to determine the epg. Fecal cultures were performed in accordance with the method of Roberts and O'Sullivan (1950). The egg count percentage reduction (ECR) was calculated using the following formula (IQBAL et al., 2006):

$$
\text { ECR }(\%)=\frac{\begin{array}{c}
\text { Pretreatment egg } \\
\text { count per gram }
\end{array}-\begin{array}{c}
\text { Post-treatment egg } \\
\text { count per gram }
\end{array}}{\text { Pretreatment egg count per gram }}
$$

\section{Statistical analysis}

For the statistical analysis, the results from the in vitro tests were analyzed using ANOVA and compared by means of the Tukey test $(P<0.05)$ (OLIVEIRA et al., 2009). The effective concentrations for inhibiting 50\% (EC50) of egg hatching and larval development were determined using the probit method (COSTA et al., 2008). The lethal doses required to kill 50\% (LD50) and $10 \%$ (LD10) of the mice were calculated for each administration route from the acute toxicity analysis using the probit method (OLIVEIRA et al., 2009). The efficacy of EcEO in relation to the FECRT results was assessed by means of nonparametric oneway Kruskal-Wallis analysis of variance, followed by Dunn's test.

\section{Results}

The inhibition of egg hatching and larval development was dose dependent. Table 1 shows the mean efficacy according to the egg hatching and larval development tests using EcEO. The EC50 for inhibition of egg hatching and larval development was $1.14(0.67-2.01)$ and $2.71(2.00-3.69) \mathrm{mg} \cdot \mathrm{mL}^{-1}$, respectively.

In the acute toxicity tests, the LD10 and LD50 calculated for oral administration were 2609 (689.7 - 3466.4) and 4153.2 (2861.8 - 5849.2) $\mathrm{mg} \cdot \mathrm{kg}^{-1}$, respectively. In the test with intraperitoneal administration, LD10 and LD50 were $478.3\left(439.8\right.$ - 505) and $622.8(603.3-645.5) \mathrm{mg} \cdot \mathrm{kg}^{-1}$, respectively.

Table 2 presents the results from the FECRT. On day 8 posttreatment, EcEO $(P<0.05)$ and ivermectin $(P<0.05)$ reduced epg significantly. The maximum FECR observed was $79.16 \%$ for ivermectin and $66.25 \%$ for EcEO on day 8 . The results relating to larvae identified in fecal cultures are presented in Table 3.

The results obtained by means of gas chromatography indicated the following main constituents and respective concentrations: alpha-pinene (1.1\%); beta-citronellol (2.9\%); (-) isopulegol (7.3\%); eucalyptol (0.8\%); beta-citronellal (71.77\%); and isopulegol (4.3\%).

\section{Discussion}

The in vitro model reported in this study demonstrated the ovicidal and larvicidal effects of essential oil of E. citriodora against H. contortus. EcEO inhibited egg hatching and larval development
Table 1. Mean percentage efficacy \pm standard error of Eucalyptus citriodora essential oil on Haemonchus contortus egg hatching and larval development.

\begin{tabular}{ccc}
\hline $\begin{array}{c}\text { Concentrations } \\
\left(\mathbf{m g} \cdot \mathbf{m L}^{-1}\right)\end{array}$ & Egg hatching & Larval development \\
\hline 10.6 & - & $99.71 \pm 0.11^{\mathrm{A}}$ \\
5.3 & $98.8 \pm 0.43^{\mathrm{A}}$ & $87.92 \pm 1.90^{\mathrm{B}}$ \\
2.65 & $97.78 \pm 0.40^{\mathrm{AE}}$ & $46.93 \pm 2.14^{\mathrm{C}}$ \\
1.32 & $48.72 \pm 3.26^{\mathrm{B}}$ & $7.08 \pm 1.68^{\mathrm{D}}$ \\
0.66 & $14.31 \pm 0.99^{\mathrm{C}}$ & $3.35 \pm 1.32^{\mathrm{D}}$ \\
0.33 & $7.78 \pm 1.08^{\mathrm{D}}$ & - \\
Tween $80(3 \%)$ & $3.12 \pm 0.45^{\mathrm{D}}$ & $3.5 \pm 0.57_{\mathrm{D}}$ \\
Positive control & $92.7 \pm 1.28^{\mathrm{E}}$ & $99.81 \pm 0.1^{\mathrm{A}}$ \\
\hline
\end{tabular}

Letters compare means in the lines. Different letters indicate significantly different values $(P<0.05)$. *Positive control for egg hatching was $0.025 \mathrm{mg} \cdot \mathrm{mL}^{-1}$ of thiabendazole and for larval development, $0.008 \mathrm{mg} \cdot \mathrm{mL}^{-1}$ of ivermectin.

at a lower concentration than done by other plants studied previously. Ethyl acetate extract of Cocos nucifera at concentrations of 5 and $80 \mathrm{mg} \cdot \mathrm{mL}^{-1}$ inhibited $100 \%$ and $97.7 \%$ of egg hatching and larval development (OLIVEIRA et al., 2009). Ethyl acetate extract of Spigelia anthelmia inhibited $83.8 \%$ of egg hatching and $83.1 \%$ of larval development at concentrations of $25 \mathrm{mg} \cdot \mathrm{mL}^{-1}$ (ASSIS et al., 2003). Aqueous extract of Annona senegalensis leaves inhibited $11.5 \%$ of egg hatching at a concentration of $7.1 \mathrm{mg} \cdot \mathrm{mL}^{-1}$ (ALAWA et al., 2003). The maximum effectiveness of essential oil of Eucalyptus globulus on eggs was $99.3 \%$ at a concentration of $21.75 \mathrm{mg} \cdot \mathrm{mL}^{-1}$ and on larvae was $98.7 \%$ at a concentration of $43.5 \mathrm{mg} \cdot \mathrm{mL}^{-1}$ (MACEDO et al., 2009).

Since the in vitro tests presented good results, the essential oil was subjected to toxicological assessment to evaluate its effect and to estimate the dose on live organisms. Substances with an $\mathrm{LD} 50$ value of $1000 \mathrm{mg} \cdot \mathrm{kg}^{-1}$ via the oral route are regarded as being safe or of low toxicity (CLARKE; CLARKE, 1977). EcEO presented low acute toxicity via the oral route but its LD50 via the intraperitoneal route was higher. The observed difference in LD50 values between oral and intraperitoneal administration may be explained by the fact that in oral administration, less of the substance is absorbed from the gastrointestinal tract, or the substance can become detoxified during liver passage. On the other hand, intraperitoneal absorption is systemic and the toxic effects are produced faster and more intensely (LOOMIS; HAYES, 1996). The high LD50 values obtained indicate that EcEO can be administered with a high degree of safety.

Investigation of chemical compounds from natural products is important for developing new anthelmintic drugs, especially in view of the vast worldwide flora (ASSIS et al., 2003). Chemical analysis on EcEO has identified substances that may be responsible for its anthelmintic activity. In essential oils, some components have a higher concentration and are known as major components. The main component of EcEO was citronellal, which has been shown activity against insects such as houseflies (LEE et al., 2003) and also against females, males and juveniles of the phytonematode Bursaphelenchus xylophilus (CHOI et al., 2007). 
Table 2. Mean efficacy and eggs per gram (epg) ( \pm standard error) of $500 \mathrm{mg} \cdot \mathrm{kg}^{-1}$ of Eucalyptus citriodora essential oil and $0.2 \mathrm{mg} . \mathrm{kg}^{-1}$ of ivermectin based on fecal egg count reduction test in goats.

\begin{tabular}{|c|c|c|c|c|}
\hline Treatments & Day 0 & Day 8 & Day 15 & Day 22 \\
\hline \multicolumn{5}{|l|}{ E. citriodora } \\
\hline Mean epg & $5266 \pm 475.9^{\mathrm{Aa}}$ & $1777 \pm 274.1^{\mathrm{Ab}}$ & $2088 \pm 247.1^{\mathrm{Ab}}$ & $2188 \pm 325.4^{\mathrm{Ab}}$ \\
\hline Efficacy (\%) & - & 66.25 & 60.34 & 58.45 \\
\hline \multicolumn{5}{|l|}{ Ivermectin } \\
\hline Mean epg & $5280 \pm 1343^{\mathrm{Aa}}$ & $1100 \pm 187.4^{\mathrm{Ab}}$ & $5230 \pm 1147^{\mathrm{Ba}}$ & $1640 \pm 415.9^{\mathrm{Ab}}$ \\
\hline Efficacy (\%) & - & 79.16 & 00.94 & 68.93 \\
\hline \multicolumn{5}{|l|}{ Water } \\
\hline Mean epg & $3550 \pm 732.2^{\mathrm{Aa}}$ & $2370 \pm 478^{\mathrm{Aa}}$ & $5000 \pm 647.4^{\mathrm{Ba}}$ & $3100 \pm 734.8^{\mathrm{Aa}}$ \\
\hline
\end{tabular}

Capital letters compare mean in the lines and small letters compare mean in the columns. Different letters indicate significantly different values $(\mathrm{P}<0.05)$.

Table 3. Percentages of larval helminths in fecal cultures from goats before and after treatment with 500 mg. $\mathrm{kg}^{-1}$ of Eucalyptus citriodora essential oil or $0.2 \mathrm{mg} \cdot \mathrm{kg}^{-1}$ of ivermectin or water.

\begin{tabular}{|c|c|c|c|c|c|c|}
\hline \multirow[t]{2}{*}{ Genera } & \multicolumn{2}{|c|}{ E. citriodora } & \multicolumn{2}{|c|}{ Ivermectin } & \multicolumn{2}{|c|}{ Water } \\
\hline & Day 0 & Day 22 & Day 0 & Day 22 & Day 0 & Day 22 \\
\hline Haemonchus sp. & 22 & 7 & 28 & 10 & 24 & 24 \\
\hline Oesophagostomum sp. & 12 & 10 & 4 & 9 & 2 & 11 \\
\hline Trichostrongylus sp. & 66 & 83 & 68 & 81 & 74 & 65 \\
\hline Total & 100 & 100 & 100 & 100 & 100 & 100 \\
\hline
\end{tabular}

In the goat fecal cultures, there was a high prevalence of Trichostrongylus spp. This may be explained by the intensive use of selective treatment of animals through application of the FAMACHA method, which is focused on management of $H$. contortus infections in sheep and goats, based on clinical identification of anemia in individual animals within a flock (REIS, 2004).

The efficacy of FECRT produced by EcEO shows that this substance is promising for use against gastrointestinal nematodes. This result is similar to the findings from other studies on essential oils. Lippia sidoides essential oil at a dose of $283 \mathrm{mg} \cdot \mathrm{kg}^{-1}$ reduced epg by $54 \%$ (CAMURÇA-VASCONCELOS et al., 2008); $500 \mathrm{mg} \cdot \mathrm{kg}^{-1}$ of Eucalyptus staigeriana essential oil reduced epg by $76.57 \%$ (MACEDO et al., 2010); and $600 \mathrm{mg} \cdot \mathrm{kg}^{-1}$ of orange oil reduced epg by $94.9 \%$ (SQUIRES et al., 2010).

Ivermectin produced a small FECR, thus indicating the presence of resistant nematodes. This is a common finding in northeastern Brazil and elsewhere (SARGISON et al., 2007; KUMSA; ABEBE, 2009). The use of essential oil would be justified even with effectiveness below $95 \%$, in situations in which synthetic anthelmintics are not recommended, such as in organic breeding or dairy production, or when the cost outweighs the benefit. Therefore, the alternative use of plants may be a useful tool, in association with other methods for controlling the gastrointestinal nematodes of small ruminants (CAMURÇA-VASCONCELOS et al., 2008).

Use of plants with moderate anthelmintic activity should still be considered, perhaps not as a total alternative to anthelmintic drugs, but as part of an integrated approach specifically designed to achieve sustainable parasite control in ruminant production systems. The role of plants in extending the use and increasing the efficacy of existing anthelmintics thus warrants study (GITHIORI et al., 2006).

E. citriodora essential oil presented promising results, but the efficacy did not reach the therapeutically required level. Further investigation of isolated fractions, at different dose levels, should be pursued.

\section{Acknowledgements}

This work received financial support from CAPES and BNB/ ETENE. Dr. Bevilaqua had a grant from CNPq. We would like to thank Felipe Cavalcante Machado and Helena Araújo da Ponte of EMBRAPA/CNPC for their assistance, and also the Bioterium of Universidade Estadual do Ceará.

\section{References}

ADAMS, R. P. Identification of Essential Oil Components by Gas Chromatography/Quadrupole Mass Spectroscopy. $4^{\text {th }}$ ed. Illinois: Allured, 2001. 456 p.

ALAWA, C. B. I. et al. In vitro screening of two Nigerian medicinal plants (Vernonia amygdalina and Annona senegalensis) for anthelmintic activity. Veterinary Parasitology, v. 113, n. 1, p. 73-81, 2003. http://dx.doi.org/10.1016/S0304-4017(03)00040-2

ASSIS, L. M. et al. Ovicidal and larvicidal activity in vitro of Spigelia anthelmia Linn. extracts on Haemonchus contortus. Veterinary Parasitology, v. 117, n. 1-2, p. 43-49, 2003. http://dx.doi.org/10.1016/j. vetpar.2003.07.021

BIZIMENYERA, E. S. et al. In vitro activity of Peltophorum africanum Sond. (Fabaceae) extracts on the egg hatching and larval development of the parasitic nematode Trichostrongylus colubriformis. Veterinary Parasitology, v. 142, n. 3-4, p. 336-343, 2006. PMid:16899339. http://dx.doi.org/10.1016/j.vetpar.2006.06.013

BRITO, J. P.; OLIVEIRA, J. E. M.; DE-BORTOLI, S. A. Toxicidade de óleos essenciais de Eucalyptus spp. Sobre Calloso bruchus maculatus (Fabr., 1775) (Coleoptera: Bruchidae). Revista de Biologia e Ciências da Terra, v. 6, n. 1, p. 96-103, 2006.

CAMURÇA-VASCONCELOS, A. L. F. et al. Anthelmintic activity of Lippia sidoides essential oil on sheep gastrointestinal nematodes. Veterinary Parasitology, v. 154, n. 1-2, p. 167-170,2008. PMid: 18423877. http://dx.doi.org/ 10.1016/j.vetpar.2008.02.023 
CHAGAS, A. C. S. et al. Efeito acaricida de óleos essenciais e concentrados emulsionáveis de Eucalyptus spp. em Boophilus microplus. Brazilian Journal of Veterinary Research and Animal Science, v. 39, n. 5, p. 247-253, 2002. http://dx.doi.org/10.1590/S141395962002000500006

CHOI, I. H. et al. Nematicidal activity of monoterpenoids against the pine wood nematode (Bursaphelenchus xylophilus). Russian Journal of Nematology, v. 15, n. 1, p. 35-40, 2007.

CIMANGA, K. et al. Correlation between chemical composition and antibacterial activity of essential oils of some aromatic medicinal plants growing in the Democratic Republic of Congo. Journal of Ethnopharmacology, v. 79, n. 2, p. 213-220, 2002. http://dx.doi. org/10.1016/S0378-8741(01)00384-1

CLARKE, E. G. C.; CLARKE, M. L. Veterinary Toxicology. London: Cassel and Collier Macmillan Publishers, 1977. p. 268-277.

COLES, G. C. et al. World Association for the Advancement of Veterinary Parasitology - WAAVP: methods for the detection of anthelmintic resistance in nematodes of veterinary importance. Veterinary Parasitology, v. 44, n. 1-2, p. 35-44, 1992. http://dx.doi. org/10.1016/0304-4017(92)90141-U

COSTA, C. T. C. et al. In vitro ovicidal and larvicidal activity of Azadirachta indica extracts on Haemonchus contortus. Small Ruminant Research, v. 74, n. 1-3, p. 284-287, 2008. http://dx.doi.org/10.1016/j. smallrumres.2007.09.003

DIEHL, M. S. et al. Prospect for anthelminthic plants in the Ivory Coast using ethnobotanical criteria. Journal of Ethnopharmacology, v. 95, n. 2-3, p. 277-284, 2004. http://dx.doi.org/10.1016/j.jep.2004.07.012

GEARY, T. G.; SANGSTER, N. C.; THOMPSON, D. P. Frontiers in anthelmintic pharmacology. Veterinary Parasitology, v. 84, n. 3-4, p. 275-295, 1999. http://dx.doi.org/10.1016/S0304-4017(99)00042-4

GITHIORI, J. B.; ATHANASIADOU, S.; THAMSBORG, S. M. Use of plants in novel approaches for control of gastrointestinal helminths in livestock with emphasis on small ruminants. Veterinary Parasitology, v. 139, n. 4, p. 308-320, 2006. PMid:16725262. http://dx.doi. org/10.1016/j.vetpar.2006.04.021

HASEGAWA, T. et al. Bioactive monoterpene glycosides conjugated with gallic acid from the leaves of Eucalyptus globulus. Phytochemistry, v. 69, n. 3, p. 747-753, 2008. PMid:17936865. http://dx.doi.org/10.1016/j. phytochem.2007.08.030

HUBERT, J.; KERBOEUF, D. A microlarval development assay for the detection of anthelmintic resistance in sheep nematodes. The Veterinary Record, v. 130, p. 442-446, 1992. PMid:1621342. http://dx.doi. org/10.1136/vr.130.20.442

IQBAL, Z. et al. In vivo anthelmintic activity of ginger against gastrointestinal nematode of sheep. Journal of Ethnopharmacology, v. 106, n. 2, p. 285-287, 2006. PMid:16443342. http://dx.doi. org/10.1016/j.jep.2005.12.031

JACKSON, F; MILLER, J. Alternative approaches to control - Quo vadit? Veterinary Parasitology, v. 139, n. 4, p. 371-384, 2006. PMid:16750600. http://dx.doi.org/10.1016/j.vetpar.2006.04.025

KUMSA, B.; ABEBE, G. Multiple anthelmintic resistance on a goat farm in Hawassa (southern Ethiopia). Tropical Animal Health and Production, v. 41, n. 4, p. 655-662, 2009. PMid:18791803. http://dx.doi.org/10.1007/s11250-008-9237-z
LEE, S.; PETERSON, C. J.; COATS, J. R. Fumigation toxicity of monoterpenoids to several stored product insects. Journal of Stored Products Research, v. 39, n. 1, p. 77-85, 2003. http://dx.doi. org/10.1016/S0022-474X(02)00020-6

LOOMIS, T. A.; HAYES, A. W. Loomis's Essentials of Toxicology. 4th ed. San Diego: Academic Press, 1996. 282p.

MACEDO, I. T. F. et al. Atividade ovicida e larvicida in vitro do oleo essencial de Eucalyptus globules sobre Haemonchus contortus. Revista Brasileira de Parasitologia Veterinária, v. 18, n. 3, p. 62-66, 2009.

MACEDO, I. T. F. et al. Anthelmintic effect of Eucalyptus staigeriana essential oil against goat gastrointestinal nematodes. Veterinary Parasitology, v. 173, n. 1-2, p. 93-98, 2010. PMid:20609526. http://dx.doi.org/10.1016/j.vetpar.2010.06.004

MAZZONETTO, F.; VENDRAMIM, J. D. Efeito de Pós de Origem Vegetal sobre Acanthoscelides obtectus (Say) (Coleoptera: Bruchidae) em Feijāo Armazenado. Neotropical Entomology, v. 32, n. 1, p. 145-149, 2003. http://dx.doi.org/10.1590/S1519-566X2003000100022

OLIVEIRA, L. M. B. et al. Anthelmintic activity of Cocos nucifera L. against sheep gastrointestinal nematodes. Veterinary Parasitology, v. 159, n. 1, p. 55-59, 2009. http://dx.doi.org/10.1016/j.vetpar.2008.10.018

PANDEY, R. et al. Essential oils as potent sources of nematicidal compounds. Journal of Phytopathology, v. 148, n. 7-8, p. 501-502, 2000. http://dx.doi.org/10.1046/j.1439-0434.2000.00493.x

RAMEZANI, H. et al. Antifungal activity of the volatile oil of Eucalyptus citriodora. Fitoterapia, v. 73, n. 3, p. 261-262, 2002. http://dx.doi. org/10.1016/S0367-326X(02)00065-5

REIS, I. F. Controle de nematóides gastrintestinais em pequenos ruminantes: método estratégico versus FAMACHA. 2004. $80 \mathrm{f}$. Dissertação (Mestrado em Ciências Veterinárias)-Universidade Estadual do Ceará, Fortaleza.

ROBERTS, F. H. S.; O'SULLIVAN, P. J. Methods for egg counts and larval cultures for strongyles infecting the gastrointestinal tract of cattle. Australian Journal of Agricultural Research, v. 1, p. 99-102, 1950. http://dx.doi.org/10.1071/AR9500099

SARGISON, N. D. et al. Observations on the emergence of multiple anthelmintic resistance in sheep flocks in the south-east of Scotland. Veterinary Parasitology, v. 145, n. 1-2, p. 65-76, 2007. PMid:17134836. http://dx.doi.org/10.1016/j.vetpar.2006.10.024

SILVA, J. et al. Analgesic and anti-inflamatory effects of essential oils of Eucalyptus. Journal of Ethnopharmacology, v. 89, n. 2-3, p. 277-283, 2003. PMid:14611892. http://dx.doi.org/10.1016/j. jep.2003.09.007

SQUIRES, J. M. et al. Efficacy of an orange oil emulsion as an anthelmintic against Haemonchus contortus in gerbils (Meriones unguiculatus) and in sheep. Veterinary Parasitology, v. 172, n. 1-2, p. 95-99, 2010. PMid:20452126. http://dx.doi.org/10.1016/j. vetpar.2010.04.017

UENO, H.; GONÇALVES, P. C. Manual para diagnóstico das helmintoses de ruminantes. Tokyo: JIICA, 1998. 143p.

VIEIRA, L. S. Métodos alternativos de controle de nematóides gastrintestinais em caprinos e ovinos. Revista Tecnologia \& Ciência Agropecuária, v. 2, n. 2, p. 49-56, 2008. 